Prof. dr. Sulejman KENDIĆ ${ }^{1}$, mr. sc. dr. Avdo ŠAKUŠIĆ ${ }^{2}$ doc. dr. Nijaz SKENDER ${ }^{3}$

${ }^{1}$ Visoka zdravstvena škola, Univerziteta u Bihaću

${ }^{2}$ Psihijatrijska klinika, Univerziteta u Tuzli

${ }^{3}$ Pedagoški fakultet, Univerziteta u Bihaću

\title{
STRES - BOLEST DANAŠNJICE, UTJECAJ NA ZDRAVLJE (stručni članak)
}

Sažetak

U psihološkom smislu, «stres je stanje koje nastaje kad su ljudi suočeni s događajima koje ocjenjuju prijetećima za svoju dobrobit ili koji od njih traže ulaganje s posebnim naporom kako bi udovoljili zahtjevima koji se pred njih postavljaju». Postoji vrlo čvrsta povezanost stresa $i$ bolesti, osobito bolesti srca i krvnih žila. Ukoliko postoji velika količina stresa, a hormoni stresa se ne iskorištavaju u nekoj fizičkoj ili drugoj produktivnoj aktivnosti, dolazi do povećanja rada srca, pojave visoki krvnog pritiska, pada imuniteta, pokretanja brojnih patofizioloških mehanizama nastanka bolesti. Stres dijeluje supresivno na urvnoteženost, adaptaciju organizma, a potpomaže slom i dekompenzaciju fizioloških funkcija.

Svi ljudi kvalitativno jednako reagiraju na stres, ali kvantitativno postoje znatne razlike. Isti uzrok stresa (stresor) neće jednako pogoditi svakog pojedinca, jer je pri tome bitna lična procjena i shvatanja ugroženosti.

Potvrdena je i znanstveno valorizirana povezanost stresa $s$ imunološkim sistemom i njegovim slabljenjem.

Osim fizičkih problema, stres je povezan $i$ s mentalnim problemima, poput poremećaja tjeskobe i depresije. Psihološki stres je poseban odnos između osobe i okoline, koji osoba procjenjuje kao vrlo zahtjevan ili kao odnos koji prelazi njezine mogućnosti i ugrožava njezinu dobrobit.

Izvori stresa su najčešći iz društvenih okolnosti $i$ to: brze promjene u našem društvu, promjene političkog sistema, poratna situacija-stanja, socijalne tenzije, promjene u zakonodavstvu vezane 
uz radno mjesto, razne reforme, promjene društvenih vrijednosti, slaba plaća, nizak socijalni status što je u neskladu s proklamiranom važnošću djelatnosti, omalovažavajući stav okoline prema poslu koji radite, nasilje.

Stres zasigurno dovodi do tjelesnnih $i$ zdravstvenih promjena, a to su: psihosomatske bolesti (čir na želucu, visok tlak, alergije, migrene), probavne smetnje, poremećaji tjelesne težine (debljanje ili mršavljenje), manja otpornost prema bolestima, poteškoće sna $i$ spavanja.

Antistresno može se djelovati: usostvaljanjem podnošljivih međuljudskih odnosa, psihoanalizom, određivanjem dostižnih ciljeva, organizacijom poslova i obveza;

Ključne riječi: stres, stresovi, stresogena reakcija, bolest.

\section{UVOD}

Porijeklo riječi stres: riječ dolazi iz engleske industrije stakla i metala gdje se je izdržljivost materijala ispitivala u laboratorijima. Odatle naziv stres. Uvriježeno je da se stres tumači kao bolest protiv otpora. Svima nama je poznata situacija u kojoj smo se, bilo privatno ili poslovno, osjećali preopterećeno i pod pritiskom, hektično ili nervozno. Tada je čovjek veoma razdražljiv, ljut ili se osjeća potlačeno, a vrlo često pada u depresiju. Prirodni princip harmonije je danas narušen jer nema više ravnoteže između aktivnosti i faze mirovanja, stresa i oporavka, napora i opuštanja.

Stres je sastavni dio života i kao takav je dobar jer podiže naše sposobnosti, ali previše stresa dovodi do narušavanja zdravlja. Dugotrajni stres nije samo uzročnik mnogih oboljenja, već indirektno se negativno odražava jer kad je čovjek pod pritiskom, tada se nezdravo hrani, više puši, poseže za alkoholom. U tom slučaju su povećane mogućnosti raznih nesreća, naše sposobnosti su oslabljene, pravimo sve više grešaka u životu jer ne razmišljamo racionalno, osjećamo se tjeskobno i potišteno. 
Medicinski definirano stres je djelovanje specifičnih vanjskih i unutarnjih utjecaja - stresova, koji izazivaju psihičke i fiziološke reakcije kod ljudi i životinja, te dovode do tjelesnog i duhovnog opterećenja. Kao stresovi se definiraju svi unutarnji vanjski utjecaji koje organizam dijeli na pozitivne i negativne u obliku podražaja. Stresovi se mogu podijeli na one koji su:

- fizičke prirode: buka, hladnoća, vrućina i sl.,

- toksične prirode: najbolji primjer za to je pušenje, jer je to za naš organizam jedan veliki stres,

- emocionalne prirode: prevelika očekivanja u životu, strahovanja, bolesti i sl.,

- socijalne prirode: siromaštvo, neriješen stambeni problem, dugovanja, poroci kojima se odajemo, bračno stanje i sl.

Stresovi su i:

- akutni, vremenski ograničeni stresovi (npr. skakanje padobranom, čekanje na operaciju, susret s divljom životinjom i sl.),

- niz događaja koji se pojavljuju tokom dužeg vremenskog razdoblja kao posljedica nekog početnog događaja kako što je gubitak posla, rastava ili smrt bliske osobe,

- kronični isprekidani stresovi, poput konfliktnih posjeta rodbini ili seksualnih teškoća, koje se mogu pojaviti jednom dnevno, jednom sedmično, jednom mjesečno, $i$

- kronični stresovi - kao što su trajni invaliditet, roditeljsko neslaganje ili kroničan stres na poslu - koji mogu, ali i ne moraju biti izazvani nekim pojedinačnim događajem, a traju dugo vremena.

\section{Savladavanje stresa znači:}

- energiju stvorenu pri stresnim reakcijama pozitivno iskorištavati (npr. rekreativno bavljenje sportom),

- analiziranje personalnih situacija u kojima se nalazimo i u kojima smo se nalazili,

- napetost i opuštanje dovoditi u skladan balans,

- samokreiranje načina za opuštanje da bismo savladali stres,

- sprečavanje nastanka štetnog djelovanja stresa na naš organizam, 
- odabrati vlastite metode, naučiti ih i konkretno u datim situacijama primijeniti.

\section{Dvije kategorije stresa}

Za stanje akutnog stresa karakterističan je doživljaj emocionalne patnje. Osoba je svjesna svoje "nervoze", uznemirenosti, tuge, potištenosti, bijesa prema sebi i drugima, pretjerane upotrebe alkohola, cigareta ili kafe, slabe koncentracije, rastresenosti, zaboravnosti, "opsjednutosti" istim mislima, te zabrinutosti za svoje psihičko stanje. Sve se to negativno odražava na kvalitet života, odnose sa ljudima i na san, te dovodi do intenziviranja stanja stresa jer - sve su to novi stresovi. Ako se osoba na vrijeme ne oslobodi stanja akutnog stresa, onda se ono razvija u stanje hroničnog stresa.

Za razliku od stanja akutnog stresa, za stanje hroničnog stresa karakteristično je odsustvo doživljaja emocionalne patnje, i to je suštinska razlika između stanja akutnog stresa i stanja hroničnog stresa. Ovo stanje nastaje tako što osoba vremenom razvija toleranciju na manifestacije akutnog stresa i navikava se na njih, ignorišući ih ili negirajući. Pošto taj proces odvlači energiju ličnosti, osoba se u sve većoj mjeri emocionalno distancira od drugih ljudi, izbjegava intimne socijalne kontakte i intimne seksualne odnose, te sve teže pronalazi zadovoljstvo u svakodnevnim aktivnostima u sadašnjosti, fokusirajući se na ciljeve u budućnosti. Tipično razmišljanje osobe u stanju hroničnog stresa je: "Dok završim još ovo..."

Osoba u stanju hroničnog stresa prepoznaje se prije svega po tome što kompulzivno radi, prisilno: osoba stalno mora biti aktivna, oko nečega zauzeta i ne može se opustiti - eventualno uz upotrebu alkohola, droga, samoinicijativno korištenje tableta za smirenje ili kroz "mehanički" seks, ali vremenom razvija toleranciju i na sve ovo. Pored kompulzivnog rada, koji je najizraženija i upadljiva manifestacija stanja hroničnog stresa, prisutni su umor, hronični nedostatak vremena, manjak motivacije, cinizam, negativizam, iritabilnost i pretjerana kritičnost prema drugima, impulzivno ponašanje, nesanica, kompulzivno bavljenje problemima s posla izvan radnog vremena, duži oporavak od bolesti - čak i od bezazlenih kao što je prehlada. Takvo stanje konačno dovodi do fizičkog kolapsa (intenzivan bol, premor, malaksalost, onesvještavanje, pseudoepileptički napadi). 


\section{Cijena neznanja i ignorisanja signala stresa}

Iako stanje akutnog stresa predstavlja signal organizma da se "nešto dešava", a stanje hroničnog stresa da je "opasnost pred vratima", osoba zbog neznanja i ignorisanja signala stresa nastavlja sa istim obrascima ponašanja i stilom života. Ponekad osobe koje pate od stanja hroničnog stresa dožive nekoliko fizičkih kolapsa (oštećujući određene neurološke funkcije ili organe u tijelu) prije nego što se obrate za stručnu pomoć.
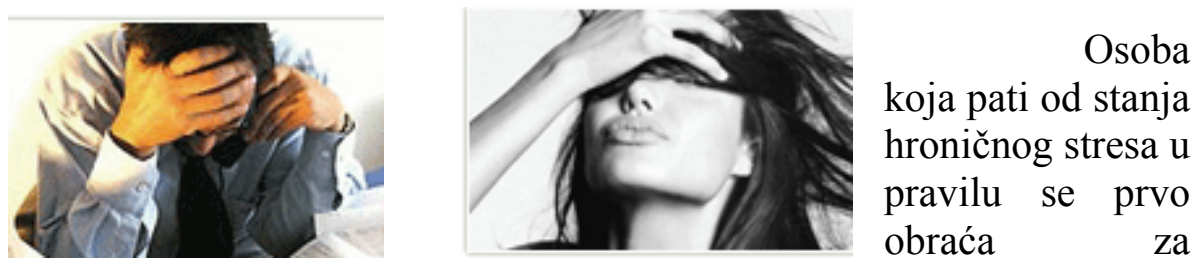

medicinsku pomoć zbog somatskih tegoba (hipertenzija, glavobolje, bolovi i ukočenost $\mathrm{u}$ vratu i leđima, napetost $\mathrm{u}$ abdominalnom predjelu). Nakon brojnih medicinskih pretraga (CT, EKG i sl.), različitih dijagnoza i terapija, obično se utvrdi da nema direktnog organskog uzroka fizičkih tegoba te se osoba na kraju obraća za psihološku pomoć. Nijedno životno razdoblje čovjeka nije pošteđeno, pa su uobičajeni izvori stresa kategorizirani prema dobi:

- 0-6 mj. - odvajanje od majke (gubitak prsiju ili bočice), glasni zvukovi;

-7-12 mj. - odvajanje od majke, stranci, nagli neočekivani objekti i glasni zvukovi;

-1-4 god. - odvajanje od roditelja, gubitak tjelesnog sadržaja, ozljede, životinje, glasni zvukovi, mrak, maske, "loši" ljudi, nasilje, noćne more;

- 5-6 god. - nadnaravna bića, mrak, nasilje, samoća, noćne more;

- 7-11 god. - socijalizacija, škola, ozljede, vlastiti izgled, selidba, smrt;

- 9-12 god. - izgled, sigurnost, autoriteti u obitelji i školi, životinje, prirodne katastrofe;

-12-25 god. (pubertet i adolescencija) - slika vlastitog tijela, sigurnost, moralno neodobravanje, problemi s pronalaženjem partnera, brige o vlastitoj budućnosti, politički događaji.

Škola je jedan od glavnih izvora stresa u djece i mlađih, a temeljni je razlog pogrešan sistem koji se bazira na sankcioniranju 
negativnog ponašanja ("ako ne napišeš zadaću, dobit ćeš jedinicu") zbog čega i prije radoznalo, zainteresirano i pametno dijete vremenom izgubi volju za radom i učenjem te zamrzi školu.

$\mathrm{Na}$ pravilan pristup još je potkraj 40-ih i početkom 50-ih godina prošlog stoljeća uputio psiholog Skinner rekavši da je za kvalitetno učenje potreban "positive reinforcement", što znači da treba nagraditi (pohvalom, ocjenom ili na neki drugi način) učenika, studenta ili djelatnika koji je nešto dobro napravio. No, onoga koji nije napravio što se od njega tražilo ili očekivalo, ne treba ni grditi ni prisiljavati (i tako stvarati dodatni stres), nego ga treba ohrabriti i potaknuti na rad i učenje, otprilike na način: "Kad i ti savladaš predviđeni program, biti ćeš nagrađen za trud."

\section{DISKUSIJA}

\section{Fiziološki odgovor tijela na stres}

Najvećim dijelom fiziološkog odgovora našeg tijela na djelovanje stresogenih činitelja upravljaju simpatiko-adrenalni (SA) i limbičko-hipotalamo-hipofizno-adrenalni (LHPA) sustav. Prije više od 50 godina Hans Selye je opisao glavna obilježja triju stadija stresa:

1. Stadij alarma karakterizira izvanredno brza aktivacija neurona simpatičnog dijela autonomnog živčanog sustava koji se nalaze u prsnom dijelu kičmene moždine. Uz ostala djelovanja, ti neuroni potiču lučenje hormona nadbubrežne žlijezde adrenalina i noradrenalina u krv. Putem aktivacije adrenergičkih staničnih receptora kateholamini adrenalin i noradrenalin gotovo trenutačno pripremaju organizam za borbu ili bijeg od opasnosti, odnosno prirodnog neprijatelja (fight or flight response): ubrzavaju frekvenciju srca, šire bronhije, centraliziraju krvotok, šire zjenice, povećavaju tonus mišića...

2. Stadij pružanja otpora obilježen je i snažnom aktivacijom LHPA sistema, što uključuje lučenje hormona koji potiče oslobađanje adrenokortikotropnog hormona (ACTH) iz hipotalamusa, koji pak izaziva lučenje ACTH iz prednjeg režnja hipofize, koji zatim dovodi do lučenja glukokortikoida kortizola iz unutarnje zone kore nadbubrežne žlijezde u krv. 
Kortizol putem glukokortikoidnih receptora djeluje na intermedijalni metabolizam (npr. povećava koncentraciju glukoze u krvi), kardiovaskularni (npr. održava povišenim već povišeni krvni tlak povećavajući osjetljivost na kateholamine), živčani (pojačano aktivira neurone u područjima središnjeg živčanog sistema odgovornim za vidno-prostorno prepoznavanje, učenje i pamćenje) i imunološki sustav (npr. inhibira rane i kasne manifestacije upale i autoimuni odgovor), sve radi konačnog odupiranja izvoru opasnosti i vraćanja organizma u prvobitno normalno stanje (u slučaju nedostatka kortizola govorimo o Addisonoj bolesti koju karakteriziraju smanjen krvni tlak, slabost mišića, depresija, anoreksija, hipoglikemija i općenito nemogućnost pružanja otpora fizičkom stresu). Osim povećana lučenja ACTH, zbog stresa dolazi i do povećana lučenja drugih peptida (npr. endogenog opioida beta-endorfina i melatonin-stimulirajućeg hormona), do povećana lučenja prolaktina, hormona rasta i glukagona te smanjena lučenja hormona koji stimuliraju štitnjaču i luteinizaciju, folikul-stimulirajućeg hormona i inzulina.

3. Stadij iscrpljenja nastupa kad se zbog dugotrajnog stresa organizam ne uspijeva vratiti u normalu, pa zbog već štetnog djelovanja dugotrajno povećane koncentracije kateholamina i kortizola nastaju psihofizički poremećaji, tj. psihosomatske bolesti. Više od 60 posto svih bolesti i poremećaja koje poznajemo zapravo su psihosomatske bolesti, odnosno mogu nastati kao posljedica prolongirana stresa

\section{Brojna i raznovrsna simptomatologija}

Neki od karakterističnih tjelesnih učinaka predugo povećane koncentracije kateholamina su lupanje i povećana frekvencija srca, otežano disanje uz povremenu hiperventilaciju, suha usta, žgaravica, gastritis, ulcerozni kolitis, povećani tonus mišića, što pri duljem trajanju onemogućuje odgovarajući protok krvi i dovodi do ukočena držanja, povećana mokrenja itd. Zbog povezanosti visoke razine stresa s određenim vrstama posla, jedan od uvriježenih naziva za navedeni skup simptoma je i menadžerska bolest. Simptomi poremećena ponašanja zbog predugo povećane koncentracije kateholamina mogu biti uznemirenost, nadražljivost i svadljivost (osoba pod jakim stresom 
sklona je reagirati neprimjereno i zbog najmanjih sitnica - crne kronike u dnevnim novinama pune su takvih neprimjerenih reakcija), stalna napetost, odnosno nemogućnost opuštanja, nervozne geste i ekspresije lica, drhtanje, agitiranost, emocionalna nestabilnost, gubitak apetita (anoreksija) ili pak prekomjerno jedenje (bulimija), nemogućnost koncentracije i prisjećanja. Kognitivni simptomi stresa uključuju osjećaj nesigurnosti, nelagode, brige, straha, panike, izbjegavanje određenih aktivnosti, pojačanu budnost, odnosno nesanicu, a osjećaj beznadnosti te negativno i kritično mišljenje o samom sebi često dovode i do depresije.

Najvažniji štetni učinci kroničnog stresa zbog produljene hiperkortizolemije su:

- Hipokalemija, retencija natrija, dislipidemija, ateroskleroza i povećani krvni tlak, uz ostale štetne činitelje i gensku predispoziciju, pridonose nastanku kardiovaskularnih bolesti.

- Atrofija mišića i preraspodjela masnog tkiva uz nereaktivnost na inzulin, hiperglikemiju i povećani apetit dovode do pretilosti. Najviše zabrinjava porast pretilosti u djece. Dok je 1982. u SAD-u samo četiri posto djece bilo pretilo, taj se postotak u 2003. popeo na 28 do 40 posto. Čak 25 posto te djece već ima neke od znakova šećerne bolesti tipa II.

- Promjene raspoloženja, koncentracije i sposobnosti pamćenja rezultat su eksitotoksičnog inzulta neurona hipokampalne formacije pokrenutog pretjeranim utijekom iona kalcija putem produljene aktivacije glukokortikoidnih receptora koje ti neuroni imaju, što je potkraj osamdesetih i početkom devedesetih godina prvi detaljno opisao Robert Sapolsky. On je sa suradnicima proučavao koncentracije kortizola i testosterona $\mathrm{u}$ majmunskih čopora $\mathrm{u}$ Africi. Rezultati su pokazali da najmanju koncentraciju kortizola (i najveću koncentraciju testosterona koja mu omogućuje najbolju koštano-mišićnu građu i snagu), tj. najmanji stupanj stresa, ima vođa čopora. Taj alfa-mužjak radi što hoće i, između ostalog, raspolaže i svim ženkama u čoporu. Što je majmun na nižoj stupnju u hijerarhiji čopora, njegova su koncentracija kortizola i nemogućnost parenja, a time i razina stresa, veći.

- Smanjen imunološki i upalni odgovor izravno su odgovorni za smanjeno zacjeljivanje rana i povećanu sklonost infekciji. 
Jedan od poznatijih eksperimenata, proveden na Sveučilištu Carnegie-Mellon, pokazao je da je virus prehlade sprejem uštrcan u nos 400 dobrovoljaca izazvao bolest u dvostruko više osoba koje su imale višu razinu izmjerena stresa. Osim navedenih učinaka, hiperkortizolemija (Cushingov sindrom) izaziva i osteoporozu, poremećaj menstrualnog ciklusa i brojne druge simptome.

Iako katkad i akutni stres može biti toliko jak da odmah izazove teški poremećaj ili bolest (npr. desetak minuta intenzivna živciranja može dovesti do čira na dvanaesniku - stres ulkus), najteže i najštetnije posljedice ipak ima kronični stres. Čak 75 do 90 posto svih posjeta liječniku opće prakse povezani su s kroničnim stresom, pa možemo reći da ti pacijenti zapravo dolaze liječniku po riječ utjehe, ohrabrenja ili odobravanja (psihoterapiju), a ne na konkretni medicinski tretman.

Liječnik nikad ne bi smio zanemariti psihološki aspekt liječenja nego bi mu, u današnje vrijeme stalnog porasta stresa, trebao posvetiti i više vremena nego inače (za što uglavnom ne postoje uvjeti). Ne treba zaboraviti da osobe koje rade stresne poslove kraće žive (npr. liječnici žive pet do devet godina kraće u odnosu na ostalu populaciju). U tih se osoba sposobnosti prilagodbe na stres brže iscrpe, pa je i proces starenja stanica, tkiva i organizma u cjelini ubrzan. To je potvrdila i najveća studija starenja - Baltimorska longitudinalna studija starenja - koja traje od 1958. i prati 1500 ljudi.

Prije dvije godine objavljeni rezultati pokazali su da je dulji životni vijek statistički povezan samo s manjom prosječnom tjelesnom temperaturom, manjom prosječnom koncentracijom inzulina i većom prosječnom koncentracijom sulfata dihidroepiandrostendiona (DHEAS), univerzalnog prekursora za nastanak androgenih i estrogenih steroida $\mathrm{u}$ perifernim tkivima. Koncentracija DHEAS najveća je u dobi od 20 do 25 godina, a zatim se postupno smanjuje na oko 10 do 20 posto vrijednosti u dobi od 80 godina. Neki od posebnih oblika stresa su trudnoća (prate je porast hormona rasta, prolaktina, korionskoga gonadotropina, placentalnog laktogena, progesterona, estrogena, itd.), gladovanje (porast glukagona, kortizola, hormona rasta, itd.), dehidracija (porast antidiuretskog hormona, aldosterona, kortizola itd.), dugotrajna izloženost hladnoći (prate je, pogotovo uz hiperinsolaciju profesionalnih skijašica, porast hormona štitne žlijezde 
trijodtironina i tiroksina, pa osobito u genski predisponiranih osoba dolazi do hipertireoze), dijabetes, posttraumatski stresni poremećaj itd.

\section{Stanja koja izazivaju stres, a stres je posljedica kronično neizlječivih bolesti}

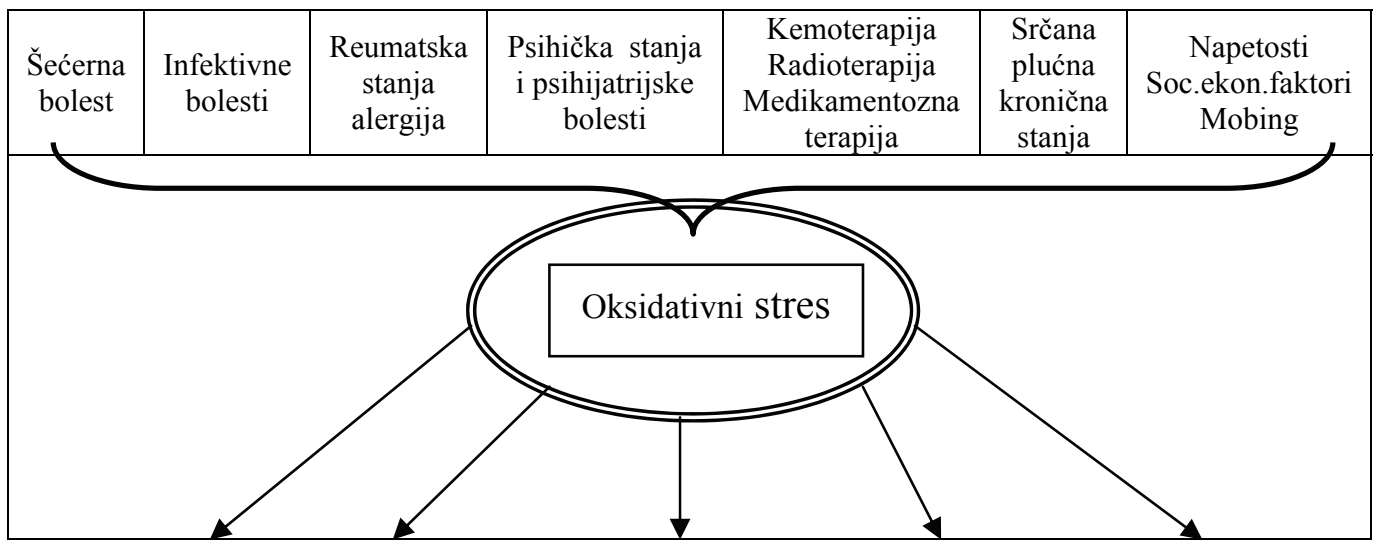

\begin{tabular}{|c|c|c|c|c|}
\hline Tumor & $\begin{array}{c}\text { Zamućenje } \\
\text { leće }\end{array}$ & $\begin{array}{c}\text { Upalni } \\
\text { procesi }\end{array}$ & Ateroskleroza & $\begin{array}{c}\text { Imunološki } \\
\text { deficiti }\end{array}$ \\
\hline
\end{tabular}

\section{Kako se odbraniti?}

Jedan je od najboljih načina za borbu protiv stresa dobro planiranje jer promišljanje i priprema za rad olakšavaju rješavanje problema. Pritom se ne misli da čovjek isplanira previše obaveza koje neće stići obaviti (pa će stres biti još veći), nego da napravi selekciju prioriteta u realnim okvirima.

Dobro je naučiti i vježbe disanja (jer za stresa dolazi do nesvjesna smanjenja broja udisaja): više puta ponoviti duboki udisaj na nos i polagani izdisaj na usta. $U$ terapiji stresa pacijentu se pomaže da sam odredi njegove izvore te vlastite negativne misli i osjećaje povezane s njima. Ujedno ga se ohrabruje i podržava u naporima da te probleme riješi. Još je poznati francuski liječnik Emil Coux 1902. istaknuo moć pozitivna mišljenja kad je u priručniku za psihološku pomoć savjetovao da bi svaka osoba tri puta poluglasno nakon buđenja i prije sna trebala sama sebi sugerirati: "Svakim danom u svakom pogledu sve više napredujem." 
U posljednjih desetak godina za smanjenje napetosti koristi se i tzv. bio-feedback, koji možemo objasniti na primjeru tenzijske glavobolje, jedne od čestih psihosomatskih bolesti uzrokovanih kroničnim stresom. Bolesnik pokušava naučiti opustiti mišiće vrata kako bi spriječio nastanak glavobolje, ali nije svjestan je li u tome uspio ili ne. Umetanjem malih elektroda u vratne mišiće za vježbanja opuštanja na aparatu se upali zelena lampica ako su se mišići doista opustili. Pacijent se tako nauči pravilno opuštati.

U novije se vrijeme i neki oblici kratkovidnosti uspješno liječe seansama opuštanja. U farmakoterapiji kroničnog stresa najviše se koriste anksiolitici (benzodiazepini) i antidepresivi, a katkad i beta blokatori i antihistaminici. No, valja upozoriti na to da anksiolitike nikako ne treba uzimati prije ispita jer izazivaju nemogućnost pamćenja (anterogradnu amneziju). Što se tiče antidepresiva, možda najvažnija činjenica na koju treba upozoriti jest da djeluju tek nakon dvije-tri sedmice, a dotad stanje može biti prolazno pogoršano. Zato se prije uzimanja antidepresiva treba obavezno konzultirati s liječnikom! Uspjeh terapije stresa obično se ocjenjuje prema sljedećim parametrima:

- osjeća li se bolesnik manje stresnim,

- prepoznaje li simptome stresa,

- obavlja li aktivnosti kojima smanjuje stres (npr. redovna tjelovježba),

- razumije li kako prihvatiti i primijeniti bolje obrasce ponašanja.

\section{ZAKLJUČAK}

Stres je stanje koje nastaje kad su ljudi suočeni s događajima koje smatraju prijetećima za svoju dobrobit ili koji od njih traže ulaganje posebnih napora kako bi udovoljili zahtjevima koji se pred njih postavljaju. Zato treba ublažavati stres i to:

- vježbanjem: lagana šetnja u prirodi, ubrzano hodanje, preskakanje konopca, vožnja biciklom, planinarenje, penjanje stubištem umjesto dizalom, poslovi u vrtu. $\mathrm{Na}$ ovaj način se oslobađamo suvišne tresne energije. Najidealnija vježba u borbi protiv stresa je joga, vježbe istezanja i vježbe jačanja mišića. 
- umirujućom kupkom sa eteričnim uljima na kraju napornog dana;

- noćnim tuširanjem prije spavanja;

- mini masažom: kod glavobolje palcem i kažiprstom pritisnuti korijen nosa; kod nervoze i razdražljivosti pritisnuti potiljak dvama prstima, te savijanjem ramena da bi se smanjila napetost u lopatici;

- prehranom: uzimati lahko probavljivu hranu (žitarice, tjestenina, krekeri), dosta voća, čak i voćnih kolača, a mlijeko i mliječni proizvodi neće preopteretiti probavni sistem; uzimati i vruću čokoladu i razne čajeve. Ne jesti prije spavanja.

- Raditi na sebi i vjerovati u sebe!

\section{LITERATURA}

1. Goleman D., Emocionalna inteligencija. Zagreb: Mozaik knjiga, 1997.

2. Grgin T., Edukacijska psihologija. Jastrebarsko: Naklada Slap, 1997.

3. Havelka M., Zdravstvena psihologija. Zagreb: Školska knjiga, 1994.

4. Krnčević J. i ostali, Stres $i$ sagorijevanje. - U: Miharija Ž. i Leko-Kolbah A. (ur.): Pomozimo djeci stradaloj u ratu. Zagreb: Ministarstvo kulture i prosvjete. Zavod za školstvo. Ured UNICEF-a u Zagrebu, 1994.

5. Kyriacou C., Temeljna nastavna umijeća. Zagreb: Educa, 1995.

6. Lindemann H., Antistres program. Zagreb: Prosvjeta 1996.

7. Perry Good E., U potrazi za srećom. Zagreb: Alinea, 1991.

8. Perry Good E., Opći smjer. Zagreb: Alinea, 1997.

9. Richard S. Lazarus i Susan Folkman, Stres, procjena $i$ suočavanje. Naklada Slap. Jastrebarsko, 2004.

10. Pregrad J., Kako ne sagorjeti na poslu.- U: Miharija Ž. i LekoKolbah A. (ur.): Pomozimo djeci strdaloj u ratu. Zagreb:

Ministarstvo kulture i prosvjete. Zavod za školstvo. Ured UNICEF-a u Zagrebu, 1994.

11. Šverko B. i suradnici, Psihologija (udžbenik za gimnazije). Zagreb: Školska knjiga, 1992.

12. Žanetić, Žanetić, Drandić, Razrednički priručnik 1998/99. Znamen. Zagreb, 1998 
13. Vlahović-Štetić V., Stres kod nastavnika. - U: Žužul M. i Raboteg-Šarić Z. (ur.), Ratni stres u djece. Zagreb: Ministarstvo obrane Republike Hrvatske, 1992

14. hhttp://www.mindtools.com/smpage.html

15. http://en.wikipedia.org/wiki/Stress \%28medicine $\% 29$

16. http://www.vasezdravlje.com/izdanje/clanak/307/0/ 
SULEJMAN KENDIĆ, P.H.D.

AVDO ŠAKUŠIĆ, P.H.D.

NIJAZ SKENDER, SENIOR LECTURER

\section{STRESS, ILLNESS OF PRESENT TIME, IMPACT ON HEALTH}

\section{SUMMARY}

In psychological sense "stress is a state which emerges when people are confronted with events that they consider threatening for their wellfare, or which require special effort in order to fulfil needs that are placed in front of them. There is a very strong link between stress and illness, especially heart and vein deseases. If there is a higher dose of stress, but stress hormons are not used in some phisical or other productive activity, this results with faster beating of the heart, higher blood pressure, fall of immunity and activating many of the pathophysical illnes mechanisms. Stress suppresses the balance and adaptation in organism, and also helps in decompensation of phisiological functions.

All people have same quality of reaction to stress, but there are great differences in quantity. The same cause of stress (stressor) will not affect different individuals in the same way, because the personal estimate and understanding of jeopardy is what matters.

The link of stess with immunological system and its weakening has been confirmed and scientificaly evaluated.

Apart from physical problems, stress is also linked with menthal problems like anxiety disturbance and depression. Psychological stess is a special relation between individual and its community, which person evaluets as a difficult or relation which surpasses its abilities and endangers its wellfare.

The sources of stress come often from social circumstances such as: Quick changes in society, Change of political system; Post - war period; Social tensions; Changes in law concerning work - place; Different reforms; Changes of social values; Low salary; Low social status which is inconsistent with proclaimed importance of the work; Belittling view of community towards the job one has, Violence.

Stress definitely causes body and health changes: psychosomatic diseases (gastric ulcer, high blood pressure, allergies, headache); digestive problems; Disturbance in body weight (fattening 
or emaciation); Lower resistance to diseases; Disturbances in sleeping.

How can we act to prevent stress: By restoring balance in organism; Psycho hygiene; By setting reachable goals; By organizing duties; Setting tolerable interpersonal relations.

Key words: stress, stressors, stress reaction, disease. 
الأستاذ الدكتور سليمان كيندينش، الأستاذ م. أفدو شاكوشيتش، و الدكتور نياز اسكندر

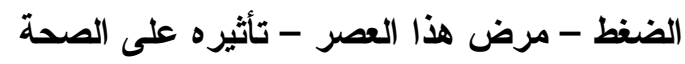

الملخص

من الناحية النفسية، الضغط هو حالة ناتجة عن مو اجهة الإنسان لأمور يحسبها تهديداً لكصالحه أو التي تستدعي منه بذل المجهود لتحقيق الأغراض الني يطلب منه نحقيقها. هناك صلة وثثقة بين الضغط و المرض، خاصة أمر اض القلب و العروق. إذا كانت كمية التية

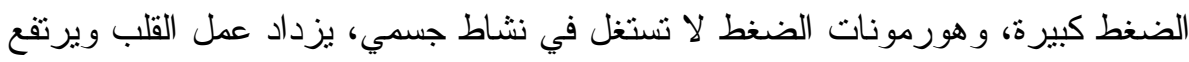
ضغط القلب، تتقص المناعة ويتحرك العديد من الآليات لحدوث المرض. الضغط له نأثئر سلبي على النو ازن وتكيف الجسم، ويساعد في الانهيار وتوقف الوظائف العنات العضلية.

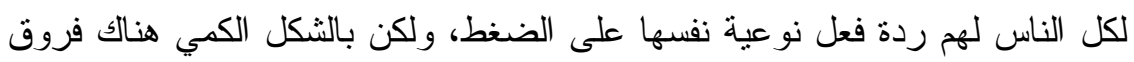

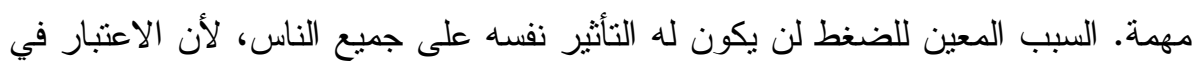

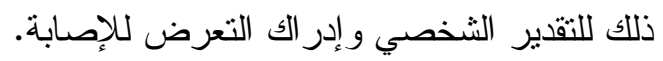
لقد أثبت العلم وقيّم وجود الارتباط بين الضغط ونظام المناعة وضعفها.

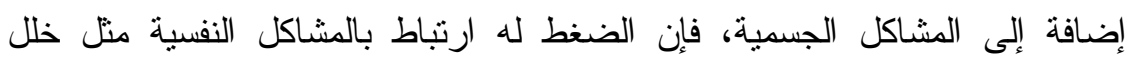

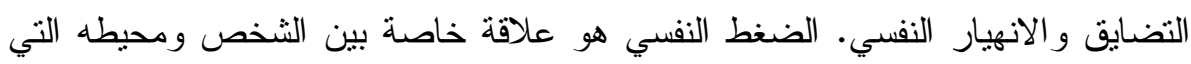
بعثبر ها الثخص مكلفةً فوق طاقته وتضر بلفيار لفصالحه.

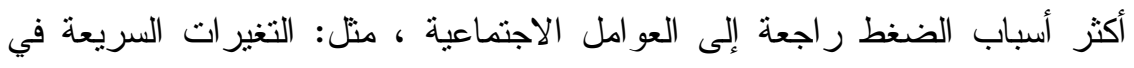

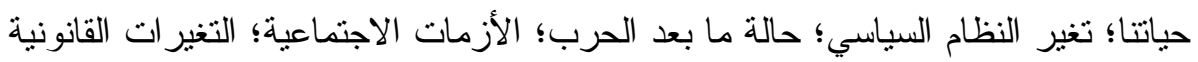

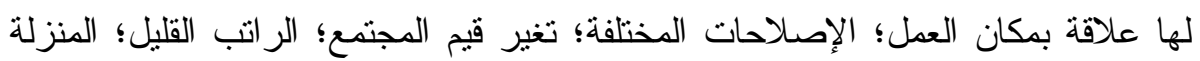

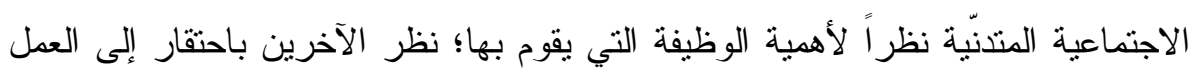

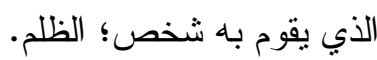
إن الضغط يؤدي إلى التغيرات الجسمية والصحية: الأمراض النفسية التي تسبب

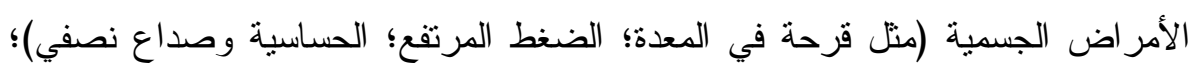

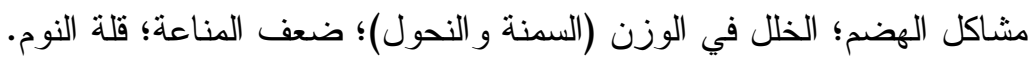


كيفية تجنب الضغط: إقامة التوازن في الجسم؛ الوقاية الصحية النفسية؛ تحقيق الأهداف التي يمكن تحقيقها؛ برمجة الأعمال و الواجبات؛ إقامة العلاقات مع الناس في حدود المعقول. 